\title{
TRENDS IN HIGHER EDUCATION IN THE ASIA-PACIFIC REGION
}

\author{
${ }^{1}$ Sh. Ibzharova, ${ }^{2}$ G. Koyanbayeva
}

\begin{abstract}
The article focuses on the trends of higher education in the countries of the Asia-Pacific region. The authors focused on the aspects of changing the landscape of global education in the direction of the Asia-Pacific region (APR), and also through the prism of cultural foundations presented models of education of the East and West. The uniqueness of the article lies in the analysis of the development of higher education in the AsiaPacific region based on a review of national and state programs for the development of higher education in the Asia-Pacific countries, reports and strategies of international organizations, and a secondary analysis of the research results of international research funds, centers, projects and individual experts.
\end{abstract}

Key words: education model, global education trends, trends in higher education in Asia, regionalization of education, mass character of education.
${ }^{1}$ Almaty Management University (AlmaU), Almaty, Kazakhstan

${ }^{2}$ Institute of Philosophy, Political Sciences and Religious Studies CS MES RK, Almaty, Kazakhstan

Corresponding Author:

Sh. Ibzharova,

sholpan68@list.ru

Reference to this article: Ibzharova Sh., Koyanbayeva G. Trends in Higher Education in the Asia-Pacific Region // Adam alemi. - 2021.

- No. 3 (89). - P. 46-61.

This research was funded by the SC MES RK (Grant No. №OR11465461 «The study of culture and values of the society in the context of sustainable development strategy of Kazakhstan»)

\section{Азия-тынық мұхиты аймағындағы елдердің жоғары білім беру жүйесіндегі трендтер}

\begin{abstract}
Аннотация. Мақалада Азия-Тынық мұхиты аймағы елдеріндегі жоғары білімнің даму трендтері қарастырылған. Авторлар ғаламдық білім ландшафтын Азия-Тынық мұхиты аймағы (APR) бағытында өзгерту аспектілеріне назар аударды, сондай-ақ мәдени негіздер призмасы арқылы Шығыс пен Батыстың білім беру үлгілерін ұсынды. Мақаланың бірегейлігі Азия-Тынық мұхиты аймағындағы жоғары білімнің дамуын Азия-Тынық мұхиты елдеріндегі жоғары білім беруді дамытудың ұлттық және мемлекеттік бағдарламаларын, халықаралық ұйымдардың есептері мен стратегияларын талдауда, сондай-ақ халықаралық зерттеу қорларының, орталықтарының, жобаларының және жеке сарапшылардың зерттеу нәтижелерін қайталама талдау негізінде жатыр.
\end{abstract}

Түйін сөздер: білім беру моделі, білім берудің жаһандық тенденциялары, Азиядағы жоғары білім үрдістері, білім беруді аймақтандыру, білім беруді жаппай тарату. 


\title{
Тренды высшего образования в странах Азиатско-Тихоокеанского региона
}

\begin{abstract}
Аннотация. В статье рассматриваются тенденции развития высшего образования в странах Азиатско-Тихоокеанского региона. Авторы сосредоточили внимание на аспектах изменения ландшафта глобального образования в сторону Азиатско-Тихоокеанского региона (ATP), а также через призму культурных оснований представили модели образования Востока и Запада. Уникальность статьи заключается в анализе развития высшего образования в ATP на основе обзора национальных и государственных программ развития высшего образования стран АТР, отчетов и стратегий международных организаций, и вторичном анализе результатов исследований международных исследовательских фондов, центров, проектов и отдельных экспертов.
\end{abstract}

Ключевые слова: модель образования, глобальные тренды образования, тренды высшего образования Азии, регионализация образования, массовизация образования.

\section{Introduction \\ Changing the Global Education Landscape}

The geographical space of the global intellectual dynamics of human civilization undergoes changes and shifts toward the Asia-Pacific region (APR) at the beginning of the third millennium. What was the cause and what are the consequences of such a "tectonic" fracture in the literal sense, since V. I. Vernadsky considered scientific thought to be a geological force in the biosphere [1991], passing into the noospheres stage of development, the peak of which falls on the third Millennium. This inevitably leads to the transformation of global education as a translator of the results of pure science into a mass society.

The content of the "education" concept includes cultural, historical, political, economic, social and humanitarian aspects. The domination of the political and economic aspects of the education issue is conceptually connected with the theory of globalization, which builds the architecture of the modern world. The ethical aspect of globalization theory contradicts the humanitarian aspect of education, which implies equality, justice and accessibility in the individual-subjective and collectiveobjective sense.

Modern American sociologist Randall Collins in his compendium "Sociology of philosophy: the global theory of intellectual change" [1] presented the evolution of human civilization through the prism of the intellectual dynamism in the three paths: Asian, Western and Islamic. Western and Islamic civilizations, due to their geographical proximity, as well as historical, cultural, religious and ideological ties, have long dominated civilizational development (the peaks of such domination are Muslim Renaissance and modern capitalism); Asian area due to its closeness from the outside world and the domination of traditionalism, tended to distinction and detachment.

The Chinese landscape of intellectual power can be summed up as an epithet of innovation through opposition; as it was shaped by rivalry and opposition of Confucianism, Taoism, and Buddhism. While the Japanese space of intellectual power has long been filled with a harmonious synthesis of Buddhism, Confucianism and Shintoism; even if paradoxically, it did not bring an intellectual explosion; innovations appeared in the era of conservatism. In the case of the Indian space, foreign and domestic political issues determined the dynamics of the intellectual world: that is, the weak state structure and the struggle of religious movements (Hinduism, Brahmanism, Jainism and Buddhism) determined seemingly static turns.

India and China have created "autochthonous" cultures and philosophical traditions equal to the European (with its American and other projections) philosophical tradition. Indian culture was projected to South-East Asia (Southeast Asia), Tibet and Mongolia, while Chinese 
culture was projected to East Asia (Korea, Japan) and Vietnam. Muslim culture as a version of the spiritual and intellectual tradition of the medieval Mediterranean [2], has influenced Malay and Indonesian cultures.

Modern British scientist and economist Angus Maddison [3] offers five stages of development of the world economy for two millennia: the 1st stage-from the beginning of the new era to 1820, the countries of Western Europe and the United States surpass China; the 2 nd stage -1820-1913, the rapid development of the economies of all countries; the 3rd stage 1913-1950, the blow of the two world wars, the great depression and the confrontation of the two systems, the "silver age"; the 4th stage - 1950-1991, the rapid pace of economic development, "Golden age"; the 5th stage-with 1991 to the present time - the transformation of socialism into capitalism, the "platinum age", the growth rate of development of the APR.

Maddison predicts a large change in the distribution of economic activity around the world by 2030. A notable feature of the projections is that by 2030, China will become the world's largest economy - nearly one-third higher than the United States - despite the decline in average growth reduced by half in recent years. India will firmly take fourth place in the world, being one of the largest economy - two-thirds of the size of Western Europe and three times bigger than in Japan, despite the fact that its growth has fallen to an average level of the silver age. Chinese and Indian shares of the world economy will grow over the next few decades, and will approach onethird by 2030 . That's in the future. However, there is a significant partial recovery in the decline relative to the Chinese and Indian economies; in one or half century, economic growth in Europe will accelerate. The four largest economies - China, USA, Western Europe, India, led by Japan will stand ahead in the next period [4].

How do these forecasts affect the state of higher education in the APR? What trends and tendencies are inherent in the real higher education of the Asia-Pacific countries? What are the current challenges in higher education in South-East Asia? How do they relate to global developments in higher education? What lessons can be learned from the study of higher education at the regional level in Asia, Southeast Asia, the Pacific, especially in the fact that regional bodies such as ASEAN, APEC, ASEAN (RFA), SCO, OECD, EAEU, etc. seek to address higher education issues?

\section{Methodology}

This paper provides a comprehensive analysis of the development of higher education in the Asia-Pacific region, which includes a review of national and state programs for the development of higher education in the APR countries [5], reports [6] and strategies of the World Bank group [7]; International Bank for reconstruction and development and the International development Association [8], the Asian development Bank [9]; the United Nations educational, scientific and cultural organization UNESCO [10]; British Council [11]; Organization for economic co-operation and development (OECD) and secondary analysis of the research results of international research funds [12], centers: National coordination center for the development of economic relations with the countries of the AsiaPacific region [13]; National research University "Higher school of Economics" [14]; SEAMEO RIHED [15]; Center for the study of international higher education at Boston College [16]; Center for Educational Development of SKOLKOVO Business School [17]; The Boston Consulting Group is an international company specializing in management consulting, a leading consultant on business strategy [18]; projects: International comparative project on financing and accessibility of higher education (ICHEFA) [19] and individual 
experts: [20], [21], [22], [23]. In this sense, the work is interdisciplinary in nature, where along with universal methods of scientific research philosophical, historical, sociological and economic approaches are used.

The method of secondary analysis is very often used in sociological research to compare and contrast data obtained from different sources [24]. In this study, it is the best tool for identifying trends in the development of higher education in the APR countries. This approach was used by researchers in the preparation of the "Report NMC Horizon: higher education 2017"; from a large array of primary studies based on secondary analysis brought a set of trends, problems and achievements as a result of their discussion by a Commission of 2000 experts in the online mode; they used a modified Delphic method for the final selection of the report topics [25].

\section{Main part \\ Geographical Data and Economic Indicators of the Region}

The Asia-Pacific region (APR) is a political and economic term that refers to countries located on the perimeter of the Pacific Ocean and numerous Island States in the ocean itself.

The Asia-Pacific region comprises 58 countries; currently, 21 States are parties to the Agreement: Australia, Bangladesh, Cambodia, China, Fiji, India, Indonesia, Japan, Republic of Korea, Malaysia, Mongolia, Myanmar, Nepal, New Zealand, Pakistan, Palau, Philippines, Singapore, Sri Lanka, Thailand and Viet Nam.

South-East Asia is a macroregion covering continental and island territories between China, India and Australia. Includes the Indochina Peninsula and the Malay Archipelago; part of the Asia-Pacific region.

The Association of Southeast Asian Nations (ASEAN) - is the political, economic and cultural regional intergovernmental organization of 10 countries (Brunei, Cambodia, Indonesia, Laos, Malaysia, Myanmar, Philippines, Singapore, Thailand, Vietnam) which is located in Southeast Asia. The ASEAN region is firmly committed to the development of education at all levels and to further social and economic integration.

Asia-Pacific economic cooperation (APEC) is the Asia-Pacific forum of 21 economics for cooperation in regional trade and investment liberalization. APEC's goal is to increase economic growth, prosperity in the region and strengthen the Asia-Pacific community. The participating economies account for about $40 \%$ of the world's population, approximately $54 \%$ of GDP and $44 \%$ of world trade.

Experts of the HEAD Singapore Foundation [26] focus in their research on the unevenness and heterogeneity of this region:

- by population: three of the four most populous countries in the world - China, India and Indonesia and small, new States;

- demographic imbalance: the decline or growth increase of young people interested in higher education, which presents different challenges for the higher education system of these countries;

- economic imbalance: along with Japan, South Korea, Singapore, Taiwan, Hong Kong, Malaysia and Thailand joined the OECD as advanced economies, as well as several States classified as developing (despite their rapid growth);

- ethnic and linguistic imbalance: along with homogeneous ones like Japan, South Korea and Vietnam, there are States having difficulty combining ethnic groups and languages such as Indonesia, China and the Philippines;

- the situation in the region is influenced by the historical past of the colonial heritage: British, French, Spanish, American, Dutch;

- political and economic imbalance between governance and free market capitalism: China's centralized market 
socialism with Singapore's regulated capitalism, and India's and Indonesia's volatile economies.

Asian development forecast for 2018 remains stable:

- regional gross domestic product (GDP) will grow by $6.0 \%$ in 2018 and $5.9 \%$ in 2019;

- lower inflation is forecast for developing Asia at 2.8\% in 2018 and $2.7 \%$ in 2019 (ADB Report);

The People's Republic of China forecasts that previous growth forecasts will be $6.6 \%$ in 2018 and $6.4 \%$ in 2019 (ADB Report);

- South Asia remains the fastest growing sub region, led by India: growth in 2018 will amount to $7.0 \%$, and in 2019 is $7.2 \%$; India plans to achieve forecasts in April to $7.3 \%$ in 2018 and $7.6 \%$ in 2019 (Report ADB)

- South-East Asia continues to be supported by strong domestic demand, especially for private consumption and investment. This year and further growth is projected at $5.2 \%$ [27].

Table 1 - characteristics of the Asia-Pacific countries

\begin{tabular}{|c|c|c|c|}
\hline \multirow{2}{*}{$\begin{array}{l}\begin{array}{l}\text { Groups of } \\
\text { countries }\end{array} \\
\text { Target } \\
\text { countries }\end{array}$} & \multicolumn{3}{|c|}{ Characteristics } \\
\hline & Economy & Religion & $\begin{array}{l}\text { Accessibility of higher } \\
\text { education }\end{array}$ \\
\hline $\begin{array}{l}\text { Cambodia, } \\
\text { Laos, } \\
\text { Mongolia, } \\
\text { Vietnam, } \\
\text { Myanmar }\end{array}$ & $\begin{array}{l}\text { Low and lower middle income, the } \\
\text { higher education system is focused } \\
\text { on the expansion and increase in the } \\
\text { number of students, the development of } \\
\text { infrastructure }\end{array}$ & $\begin{array}{l}\text { Buddhism } \\
\text { (Mahayana) } \\
\text { Confucianism } \\
\text { Taoism }\end{array}$ & $\begin{array}{l}\text { Myanmar - } 10 \% \\
\text { Cambodia and Laos } \\
-<20 \% \\
\text { Mongolia - } 68 \%(2015)\end{array}$ \\
\hline $\begin{array}{l}\text { Indonesia, } \\
\text { Malaysia, } \\
\text { Philippines, } \\
\text { Sri Lanka, } \\
\text { Thailand }\end{array}$ & $\begin{array}{l}\text { Middle - income countries with a well-es- } \\
\text { tablished and growing higher education } \\
\text { system; focus on improving quality }\end{array}$ & $\begin{array}{l}\text { Islam } \\
\text { Christianity } \\
\text { Buddhism } \\
\text { Hinduism }\end{array}$ & $\begin{array}{l}\text { Indonesia - 32\% } \\
\text { Malaysia - 37\% }\end{array}$ \\
\hline India, China & $\begin{array}{l}\text { The largest higher education systems in } \\
\text { the world and the fastest growing sys- } \\
\text { tems in East Asia; high level of education } \\
\text { policies and practices, closely monitoring } \\
\text { and influencing through other systems } \\
\text { on higher education in the region }\end{array}$ & $\begin{array}{l}\text { Islam } \\
\text { Hinduism } \\
\text { Buddhism } \\
\text { Confucianism }\end{array}$ & \\
\hline $\begin{array}{l}\text { Hong Kong, } \\
\text { Singapore, } \\
\text { Brunei }\end{array}$ & $\begin{array}{l}\text { Small, high-income countries with } \\
\text { mature and recognized higher education } \\
\text { systems. which are characterized slow or } \\
\text { stagnant pace }\end{array}$ & $\begin{array}{l}\text { Confucianism } \\
\text { Buddhism } \\
\text { Taoism } \\
\text { Islam } \\
\text { other } \\
\text { denominations }\end{array}$ & Singapore - 87\% \\
\hline $\begin{array}{l}\text { Japan, South } \\
\text { Korea }\end{array}$ & $\begin{array}{l}\text { Mature higher education systems are } \\
\text { of high quality but are experiencing a } \\
\text { decline in student enrollment }\end{array}$ & $\begin{array}{l}\text { Buddhism } \\
\text { Shinto } \\
\text { Christianity } \\
\text { Confucianism } \\
\text { Shamanism }\end{array}$ & \\
\hline
\end{tabular}

\section{Cultural Foundations and Models of Education: East and West}

The traditional opposition between Western and Eastern types of thinking is based on ideological and axiological differences between types of cultures, which are expressed in the known dichotomies: collectivism and individualism; awareness and skill, modesty and self-confidence; modernism and traditionalism, etc., which sometimes reflect a well-known assumption 
and prejudice about the superiority of Western thinking and behavior.

Modern integration processes in the educational systems of the global world demonstrate interesting synthesis results: a conceptual difference between the Western model of reason and the East Asian model of virtue [28, p.385].

The East Asian student "transforms himself" on the basis of Confucian principles, focuses on his inner world in order to improve himself, to gain his authenticity and integrity, to become morally and socially perfect (model of virtue). The purpose of education is to promote the synthesis of society with the collective and interpersonal orientation of culture. The extreme consequences of this model are repetition and cramming, emphasis on memorization, focus on the authority of the teacher.

The goal of the Western student "to learn how to manage the Universe" according to the principles of Socratic philosophy: to cultivate oneself and their mind to understand and master the world, emphasizing the outside world, critical thinking, knowledge of the world of things in the Universe, represented by science (model of mind). The purpose of such education is to teach how "to do", therefore the Western student must achieve personal goals related to individuality and selfactualization of orientation. The extreme consequences of this model are "master of the world", conqueror, success and predatory goals.

To ensure the prospects for the development of education not only in the Asian region, but also in the global world, it is necessary to focus not on the contrast, but on the balance of YinYang. An example of modern models of education that contribute to the painless reform of young Asian educational systems are the Japanese and Singapore models of education presented during the seminar "Models of education in Japan and Singapore, transfer of education and comparative education policy" held on August 26, 2016 [29]. The event was organized by the HEAD Foundation (THF) and jointly with the Center for excellence in school education of Tokyo University graduate school of education.

Two concepts of the Japanese model of education, which received international status: "Toccata" and "Study lessons". The Japanese model is formed from the concept of "holistic education" (cognitive, social, emotional and physical development of students on the basis of democratic principles). The purpose of "Toccata" - the development of emotional intelligence through the encouragement of child's activities, self-motivation, collaborative learning and self-education. Another concept of "Study lessons" are more focused on teachers, because it pays attention to training and cooperation in the process of exchange of experience on conducting lessons. Both models are applicable to the multicultural world of developing Asia.

The experience in the management and legitimacy of the education system in Singapore, for example, represents a successful bilingual policy, which took decades to build up and also contributes to the solution of problems of educational policies in developing Asian countries.

Using an example of the National University of Singapore and Nanyang University of Technology, included in the rating OF the 2018, Professor George Cheryan raises the question of the University's mission as a center of culture, science and education and its role in the development and creation of society. Formal criteria and rating standards are not correlated with local problems that can be only solved at the interdisciplinary level, in the context of the human sciences (for example, articles on the history of Singapore, do not arouse the interest of researchers in Western indexed journals). Humanitarian and civilizational components of the University, as a platform 
for critical discussion and solutions to local problems, outweighed by the government for the sake of ratings, providing diplomas (massovisation) and the order fulfillment industry. The formalization of the idea of the University for the sake of achieving world rankings by Asian universities deprives them of connection with the society of which they are a part [30].

The public need for accessible education; the increase in the number and expansion of the area of universities; the economic demands of society in qualified staff; the decline in the quality of education; the race for world rankings, etc. - led to the diversification of universities in all educational landscapes of the global world. In the Western world, this has led to the increasing complexity of the main segment in the systemic complex of society, which for its part, hassled to the adoption of the Hamburg Declaration "Organizing Higher education for the XXI century. The role of research universities" (The Hamburg Declaration Organizing Higher Education for the 21st Century, 2017) by the Union of rectors, the main provisions of which are also relevant for the developing system of Asian higher education:

- "The research university, as the apex academic institution, is central to the global knowledge economy. It educates leaders, scientists and scholars who serve society, academe, industry, and the broader economy. It conducts research, and is the window to international science.

- Research universities are central to the success of higher education, and contribute to the common good.

- Permeability: There should be articulation mechanisms that permit students equitable access to postsecondary education, allowing them to easily shift from one type of institution to another without loss of academic standing.

- Coherence: Private higher education, the fastest growing part of post-secondary education globally, requires careful integration into an effective post-secondary education system" [31, p. 10-11].
Economic demands and access to education, political government programs of governments have accelerated the shift of the global balance of power in higher education towards Asia, who has become the world's third largest zone of higher education, science and innovation after North America, Western Europe (UK).

- Asia-Pacific universities from 38 countries in East Asia, Southeast Asia and Oceania are represented in the Times Higher Education 2018 ranking (21). The overall ranking includes more than 250 universities from 13 different countries: the most representative are Japan (89), China (63), Australia (35), Taiwan (31), South Korea (27) and Thailand (10). The University of Melbourne is the only University outside Asia, taking third place among the five leaders, taking third place (last year 4th place). Other universities like the national University of Singapore (1st place), Tsinghua University (2nd place), Beijing University (3rd place) and University of Hong Kong (5th place) are included in the top five.

- The summit of Asian universities was held from 5 to 7 February 2018 in Shenzhen (China), organized jointly with SUSTech (southern University of science and technology) and Times Higher Education Rankings (THE), which raised issues of cooperation, integration and search for new ways of development of universities in the West and Asia [32]. China has found its way to creating a worldclass University model instead of copying Western models, as Shanghai University President Jao Tong Zhang Jie claims. Three key steps are needed to change ordinary universities: stimulating research; creating of new research groups; and reforming the structure of the University in order to create a sustainable culture of innovation. They included different measures to change the University culture such as monetary incentives for teachers for publishing articles, consistent transition to applied research, problem-oriented research, and 
involvement of internationally recognized researchers.

- The Alliance of Asian universities (AUA) (15 universities from 14 countries) was established at the initiative of Tsinghua University (Beijing) to strengthen the role of higher education in the development of Asian society which implied strengthening the academic mobility within the Asian region and resist the departure of professors and students to the West; strengthening the research cooperation between the teaching staff; promoting the exchange of higher education policy between the presidents of universities within the AUA; publication of the annual report on higher education in Asia; in addition, Tsinghua University funded the new organization with a onetime Deposit of \$ 1.5 million [33].

Along with high-quality universities (for example, the national University of Singapore, which is stronger than Australian Universities), there are medium-sized technical schools and other universities seeking to get into the League of the world's leading universities. Unfortunately, most of them are trying to copy Western universities on the basis of funding and some innovative strategies. The problem is in the contradiction between Eastern and Western cultures and their values; lack of cultural perspective for traditional ways of thinking; forgery of own identities; conflict between Western and own values of higher education; pragmatic approach in the adoption of the Western model led to the achievements of natural Sciences and technology and to the stagnation of the Humanities and Social Sciences. The University has three levels: material, institutional and a factor of value; material level prevails, institutional one begins to develop; cultural integration is necessary, the incorporation of Western values into the Eastern; advantage is in the synthesis of two cultures at the institutional and individualpersonal levels.
The conclusion of the special study called "Combining Chinese and Western educational tradition: a comparative analysis of strategies for building worldclass universities in mainland China, Hong Kong, Taiwan and Singapore", which was supported by the Hong Kong research funding Council (grant number $751313 \mathrm{H}$ ) on the state of University development in Southeast Asia is promising: "tremendous progress has been made despite all the difficulties, and there is reason to believe that it will achieve even more by combining the values of Western culture and its traditions. Advanced universities in East Asia have chosen an alternative path of development. Their experiment shows that it is possible to find a balance between local and Western ideas about the University, which are considered to be mutually exclusive. Although it is too early to talk about the success of this East Asian experiment, the current processes can certainly be described as promising" [34].

Higher education experts are unanimous in the need for a science-based and valueoriented approach to maintain the rational structure of the higher education system, which implies: a clear differentiation of universities (mission, control system, academic differentiation); autonomy; stable funding; quality control system; mechanisms of equal access and transition to universities for students; moral leadership and commitment to their mission of research universities; and internal connectivity of universities [35].

\section{Trends in Higher Education in Asia-Pacific countries}

\section{- Regionalization}

and its fragmentation (HEAD Foundation (Human Capital \& Education for Asian Development) [36], which can be remedied by developing effective ways of sharing knowledge and resources among different networks and equalizing their positions. 
Table 2 - Regionalization of Higher Education in the Asia-Pacific region

\begin{tabular}{|c|c|c|c|c|}
\hline \begin{tabular}{c|c|} 
Subject of \\
Regionalization
\end{tabular} & Purposes & Positive side & Negative side & Decision \\
\hline $\begin{array}{l}\text { The Association } \\
\text { of Southeast } \\
\text { Asian Nations } \\
\text { (ASEAN)v(Asian } \\
\text { Development } \\
\text { Bank, 2012). }\end{array}$ & $\begin{array}{l}\text { Cooperation } \\
\text { based on the } \\
\text { principles of } \\
\text { political stabili- } \\
\text { ty and security; } \\
\text { promotion of } \\
\text { the formation } \\
\text { of national } \\
\text { States after } \\
\text { the success } \\
\text { of national } \\
\text { liberation } \\
\text { movements }\end{array}$ & $\begin{array}{l}\text { Creation of com- } \\
\text { mon space of the } \\
\text { higher education } \\
\text { in East Asia and } \\
\text { experience of col- } \\
\text { laboration in this } \\
\text { direction }\end{array}$ & $\begin{array}{l}\text { The duplicating or } \\
\text { mutually exclusive } \\
\text { interregional and } \\
\text { intraregional political } \\
\text { and economic inter- } \\
\text { relations: The ASEAN } \\
\text { and SEAMEO want to } \\
\text { expand the Network } \\
\text { of the AUN and AIMS } \\
\text { universities in the } \\
\text { northeast direction: } \\
\text { China, Korea and } \\
\text { Japan. }\end{array}$ & $\begin{array}{l}\text { The SEAMEO region- } \\
\text { al Institute of higher } \\
\text { Education and devel- } \\
\text { opment and the Asian } \\
\text { development Bank have } \\
\text { started to develop a } \\
\text { tool known as the uni- } \\
\text { fied System of transfer } \\
\text { and accumulation of } \\
\text { academic credits (ACT- } \\
\text { FA), which is focused on } \\
\text { the entire region }\end{array}$ \\
\hline $\begin{array}{l}\text { Organization } \\
\text { of Ministers of } \\
\text { education of } \\
\text { South-East Asia } \\
\text { (SEAMEO)(Strat- } \\
\text { egy 2020, 2030; } \\
\text { Asian Develop- } \\
\text { ment Bank, 2011, } \\
\text { 2012) }\end{array}$ & $\begin{array}{l}\text { Regional inter- } \\
\text { governmental } \\
\text { organization } \\
\text { established in } \\
1965 \text { between } \\
\text { the govern- } \\
\text { ments of } \\
\text { South-East Asia } \\
\text { for assistance } \\
\text { to regional } \\
\text { cooperation } \\
\text { in the field } \\
\text { of education, } \\
\text { science and } \\
\text { culture in the } \\
\text { region }\end{array}$ & $\begin{array}{l}\text { Non-profit, non- } \\
\text { political flexible } \\
\text { organization; } \\
\text { unique programs; } \\
\text { powerful } \\
\text { infrastructure; } \\
\text { network of } \\
\text { contacts at the } \\
\text { regional and } \\
\text { international levels } \\
\text { development } \\
\text { of human } \\
\text { resources, high } \\
\text { competence and } \\
\text { professionalism of } \\
\text { employees; } \\
\text { interaction with } \\
\text { other countries } \\
\text { outside Asia }\end{array}$ & $\begin{array}{l}\text { The duplicating or } \\
\text { mutually exclusive } \\
\text { interregional and } \\
\text { intraregional political } \\
\text { and economic inter- } \\
\text { relations: The ASEAN } \\
\text { and SEAMEO want to } \\
\text { expand the Network } \\
\text { of the AUN and AIMS } \\
\text { universities in the } \\
\text { northeast direction: } \\
\text { China, Korea and } \\
\text { Japan. }\end{array}$ & $\begin{array}{l}\text { The SEAMEO region- } \\
\text { al Institute of higher } \\
\text { Education and devel- } \\
\text { opment and the Asian } \\
\text { development Bank have } \\
\text { started to develop a } \\
\text { tool known as the uni- } \\
\text { fied System of transfer } \\
\text { and accumulation of } \\
\text { academic credits (ACT- } \\
\text { FA), which is focused on } \\
\text { the entire region }\end{array}$ \\
\hline $\begin{array}{l}\text { Tripartite inter- } \\
\text { governmental } \\
\text { Panel } \\
\text { China, Japan, } \\
\text { South Korea: } \\
\text { trilateral student } \\
\text { mobility pro- } \\
\text { gram CAMPUS } \\
\text { Asia (Collective } \\
\text { Action for Mo- } \\
\text { bility Program } \\
\text { of University } \\
\text { Students in Asia) }\end{array}$ & $\begin{array}{l}\text { Formation of a } \\
\text { pool of quali- } \\
\text { fied Asian ex- } \\
\text { perts through } \\
\text { the creation of } \\
\text { a platform for } \\
\text { the exchange } \\
\text { of resources } \\
\text { and knowl- } \\
\text { edge; } \\
\text { mitigating } \\
\text { China's and } \\
\text { Korea's brain } \\
\text { drain problem }\end{array}$ & $\begin{array}{l}\text { Conditions } \\
\text { for mobility of } \\
\text { employees and } \\
\text { undergraduate } \\
\text { and graduate } \\
\text { students through } \\
\text { credit transfer and } \\
\text { implementation of } \\
\text { double and joint } \\
\text { diploma programs; } \\
\text { stimulating inter- } \\
\text { national demand } \\
\text { for local univer- } \\
\text { sities in light of } \\
\text { population decline } \\
\text { in Korea and Japan }\end{array}$ & $\begin{array}{l}\text { the duplicating or } \\
\text { mutually exclusive } \\
\text { interregional and } \\
\text { intraregional political } \\
\text { and economic inter- } \\
\text { relations: } \\
\text { China - Korea - } \\
\text { Japan plans to invite } \\
\text { other ASEAN and/or } \\
\text { SEAMEO countries } \\
\text { to the CAMPUS Asia } \\
\text { program }\end{array}$ & $\begin{array}{l}\text { CAMPUS Asia develops } \\
\text { its own credit transfer } \\
\text { system and its own } \\
\text { quality control system }\end{array}$ \\
\hline $\begin{array}{l}\text { ACEAH (AUN) } \\
\text { Sub-regional } \\
\text { platform }\end{array}$ & $\begin{array}{l}\text { International } \\
\text { system provid- } \\
\text { ing training of } \\
\text { highly qualified } \\
\text { and motivated } \\
\text { specialists }\end{array}$ & $\begin{array}{l}\text { Sub-regional } \\
\text { Service quality } \\
\text { assurance (AUN- } \\
\text { QA) and System } \\
\text { transfer of credits } \\
\text { (ACTS) carries } \\
\text { out the exchange } \\
\text { of teachers, } \\
\text { researchers, } \\
\text { administrative staff } \\
\text { and students from } \\
30 \text { universities- } \\
\text { members }\end{array}$ & $\begin{array}{l}\text { Fight for distribution } \\
\text { of resources }\end{array}$ & $\begin{array}{l}\text { The SEAMEO region- } \\
\text { al Institute of higher } \\
\text { Education and devel- } \\
\text { opment and the Asian } \\
\text { development Bank have } \\
\text { started to develop a } \\
\text { tool known as the uni- } \\
\text { fied System of transfer } \\
\text { and accumulation of } \\
\text { academic credits (ACT- } \\
\text { FA), which is focused on } \\
\text { the entire region }\end{array}$ \\
\hline
\end{tabular}




\begin{tabular}{|c|c|c|c|c|}
\hline $\begin{array}{l}\text { SEAMEO (RIHED) } \\
\text { Regional Insti- } \\
\text { tute of higher } \\
\text { education and } \\
\text { development } \\
\text { (Strategic pro- } \\
\text { grams for the } \\
\text { development of } \\
\text { higher education } \\
\text { in South-East } \\
\text { Asia) }\end{array}$ & $\begin{array}{l}\text { Creating a } \\
\text { network of } \\
\text { higher educa- } \\
\text { tion in South- } \\
\text { east Asia in } \\
\text { SEA-HEA space }\end{array}$ & $\begin{array}{l}\text { Pilot mobility } \\
\text { project for } \\
\text { Malaysia, } \\
\text { Indonesia and } \\
\text { Thailand (MIT); } \\
\text { ASEAN quality } \\
\text { assurance network } \\
\text { (AQAN); } \\
\text { South East Asia } \\
\text { credit transfer } \\
\text { system (SEA-CTS); } \\
\text { Credit transfer } \\
\text { System (UCTS); } \\
23 \text { universities, } \\
1130 \text { students } \\
\text { (2010-2014) on } \\
\text { academic mobility } \\
\text { were trained }\end{array}$ & $\begin{array}{l}\text { Along with such } \\
\text { major players in the } \\
\text { Southeast Asian } \\
\text { region as China, } \\
\text { Japan and South } \\
\text { Korea, Thailand from } \\
\text { a geopolitical and } \\
\text { geo-economic point } \\
\text { of view pursues the } \\
\text { interests of develop- } \\
\text { ing and heteroge- } \\
\text { neous Southeast Asia }\end{array}$ & $\begin{array}{l}\text { Enhancing the effec- } \\
\text { tiveness and harmo- } \\
\text { nization of higher } \\
\text { education in South-East } \\
\text { Asia through systematic } \\
\text { research, empower- } \\
\text { ment, cooperation and } \\
\text { development of mecha- } \\
\text { nisms to facilitate the } \\
\text { exchange of informa- } \\
\text { tion in higher education }\end{array}$ \\
\hline $\begin{array}{l}\text { MIT (Malaysia, } \\
\text { Indonesia, Thai- } \\
\text { land) } \\
\text { (The Malay- } \\
\text { sian education } \\
\text { plan MEBHE, } \\
\text { 2015-2020; } \\
\text { The national } \\
\text { strategic plan for } \\
\text { higher education } \\
\text { in the field of } \\
\text { education for } \\
\text { the period up to } \\
\text { 2020 (NHESP); } \\
\text { Executive Sum- } \\
\text { mary Malaysia } \\
\text { Education Blue- } \\
\text { print 2015-2025 } \\
\text { (Higher Educa- } \\
\text { tion), 2015) }\end{array}$ & $\begin{array}{l}\text { Academic } \\
\text { mobility }\end{array}$ & $\begin{array}{l}\text { With the } \\
\text { promotion of } \\
\text { university mobility } \\
\text { in the Asia-Pacific } \\
\text { Credit transfer } \\
\text { System (UCTS), } 23 \\
\text { universities under } \\
\text { MIT facilitated the } \\
\text { exchange of } 1,130 \\
\text { students during } \\
\text { the four-year } \\
\text { deployment of the } \\
\text { initiative (2010- } \\
\text { 2014). Currently, } \\
\text { MIT is moving } \\
\text { forward under a } \\
\text { broader branding, } \\
\text { the ASEAN } \\
\text { International } \\
\text { Mobile Association } \\
\text { (AIMS) and plans } \\
\text { to expand its } \\
\text { competence to } \\
\text { include four more } \\
\text { countries: Brunei } \\
\text { Darussalam, Japan, } \\
\text { the Philippines and } \\
\text { Vietnam }\end{array}$ & $\begin{array}{l}\text { It aims to create a } \\
\text { sense of ASEAN citi- } \\
\text { zenship and identity } \\
\text { among young people } \\
\text { and is widely regard- } \\
\text { ed as the flagship } \\
\text { program to enhance } \\
\text { higher education } \\
\text { mobility through } \\
\text { ASEAN initiatives to } \\
\text { enhance people-to } \\
\text { - people interaction. } \\
\text { The basic principle } \\
\text { of the AIMS program } \\
\text { is the concept of } \\
\text { balanced mobility }\end{array}$ & $\begin{array}{l}\text { AIMS, of course, is a } \\
\text { valuable program that } \\
\text { should be expanded } \\
\text { to include all ASEAN } \\
\text { member States, includ- } \\
\text { ing Singapore; some } \\
\text { experts believe that } \\
\text { ASEAN has an analogue } \\
\text { of the EU and the Bolo- } \\
\text { gna Declaration in the } \\
\text { Asian space; } \\
\text { The heterogeneous ca- } \\
\text { pacities of countries in } \\
\text { South-East Asia should } \\
\text { be taken into account, } \\
\text { rather than homoge- } \\
\text { neous as in the EU; } \\
\text { the EU is experiencing } \\
\text { certain contradictions } \\
\text { that should be taken } \\
\text { into account }\end{array}$ \\
\hline $\begin{array}{l}\text { "ASEAN plus 3" } \\
\text { +China, Korea, } \\
\text { Japan }\end{array}$ & $\begin{array}{l}\text { Overcoming } \\
\text { Asian financial } \\
\text { crisis of } 1997\end{array}$ & $\begin{array}{l}\text { Cooperation with } \\
\text { China, Korea and } \\
\text { Japan }\end{array}$ & $\begin{array}{l}\text { The contradiction of } \\
\text { "ASEAN plus 1"; } \\
\text { prioritization of } \\
\text { areas may weaken } \\
\text { the process of } \\
\text { strengthening } \\
\text { cooperation in } \\
\text { the region and } \\
\text { slow down the } \\
\text { implementation } \\
\text { of regionalization } \\
\text { programs by } \\
\text { overlapping } \\
\text { members, as a } \\
\text { result of which the } \\
\text { formation of a single } \\
\text { East Asian higher } \\
\text { education area may } \\
\text { be under threat }\end{array}$ & $\begin{array}{l}\text { Strengthening cooper- } \\
\text { ation between various } \\
\text { regional networks } \\
\text { existing in East Asia; } \\
\text { soften geopolitical } \\
\text { tensions; } \\
\text { develop effective ways } \\
\text { of sharing knowledge } \\
\text { and resources between } \\
\text { different networks } \\
\text { in order to balance } \\
\text { the positive effect } \\
\text { of regionalization in } \\
\text { higher education in all } \\
\text { countries of East Asia }\end{array}$ \\
\hline
\end{tabular}




\begin{tabular}{|c|c|c|c|c|}
\hline $\begin{array}{l}\text { ASEAN Plus } 6 \\
+ \text { Australia, } \\
\text { India, New } \\
\text { Zealand }\end{array}$ & $\begin{array}{l}\text { Dialogue } \\
\text { around the } \\
\text { development } \\
\text { of cooperation } \\
\text { in the field of } \\
\text { higher educa- } \\
\text { tion }\end{array}$ & $\begin{array}{l}\text { Improving } \\
\text { intercultural } \\
\text { understanding, } \\
\text { knowledge trans- } \\
\text { fer, labor market } \\
\text { development, } \\
\text { maintaining stabili- } \\
\text { ty and peace in the } \\
\text { region }\end{array}$ & $\begin{array}{l}\text { The need to link } \\
\text { cultures, languages, } \\
\text { educational stan- } \\
\text { dards of different } \\
\text { countries, as well } \\
\text { as national norms } \\
\text { and laws, especially } \\
\text { in the field of visa } \\
\text { policy and academic } \\
\text { calendar }\end{array}$ & $\begin{array}{l}\text { Strengthening cooper- } \\
\text { ation between various } \\
\text { regional networks } \\
\text { existing in East Asia; } \\
\text { soften geopolitical } \\
\text { tensions; } \\
\text { develop effective ways } \\
\text { of sharing knowledge } \\
\text { and resources between } \\
\text { different networks } \\
\text { in order to balance } \\
\text { the positive effect } \\
\text { of regionalization in } \\
\text { higher education in all } \\
\text { countries of East Asia }\end{array}$ \\
\hline $\begin{array}{l}\text { ASEAN Plus } 1 \\
\text { (i.e. ASEAN plus } \\
\text { Japan) }\end{array}$ & $\begin{array}{l}\text { Japan's invest- } \\
\text { ment in region- } \\
\text { al development }\end{array}$ & $\begin{array}{l}\text { Improving } \\
\text { intercultural } \\
\text { understanding } \\
\text { knowledge trans- } \\
\text { fer, labor market } \\
\text { development, } \\
\text { maintaining stabili- } \\
\text { ty and peace in the } \\
\text { region }\end{array}$ & $\begin{array}{l}\text { The contradiction of } \\
\text { "ASEAN plus } 3 \text { "; } \\
\text { can weaken the } \\
\text { process of strength- } \\
\text { ening cooperation in } \\
\text { the region and slow } \\
\text { down the implemen- } \\
\text { tation of regional- } \\
\text { ization programs } \\
\text { by overlapping } \\
\text { members }\end{array}$ & $\begin{array}{l}\text { The SEAMEO region- } \\
\text { al Institute of higher } \\
\text { education and devel- } \\
\text { opment and the Asian } \\
\text { Development Bank } \\
\text { have started to develop } \\
\text { a tool known as the } \\
\text { unified System of trans- } \\
\text { fer and accumulation of } \\
\text { academic credits (ACT- } \\
\text { FA), which is focused on } \\
\text { the entire region }\end{array}$ \\
\hline $\begin{array}{l}\text { ACEAN (SHARE) } \\
\text { Among ASEAN's } \\
\text { closest dialogue } \\
\text { partners is the } \\
\text { European Union } \\
(E U) \text {. In 2017, the } \\
\text { EU and ASEAN } \\
\text { celebrate the } \\
\text { 40th anniversary } \\
\text { of formal coop- } \\
\text { eration at the } \\
\text { 10th Ministerial } \\
\text { meeting in } 1977\end{array}$ & $\begin{array}{l}\text { The objec- } \\
\text { tives of the } \\
\text { program are } \\
\text { to strengthen } \\
\text { regional co- } \\
\text { operation and } \\
\text { improve the } \\
\text { quality, com- } \\
\text { petitiveness } \\
\text { and interna- } \\
\text { tionalization of } \\
\text { higher educa- } \\
\text { tion institutions } \\
\text { and ASEAN } \\
\text { students, the } \\
\text { Area of SHARE } \\
\text { results with } \\
\text { which EU and } \\
\text { ASEAN part- } \\
\text { ners cooperate }\end{array}$ & $\begin{array}{l}\text { AEAN Qualifi- } \\
\text { cation Reference } \\
\text { Frameworks } \\
\text { (AQRF) and ASEAN } \\
\text { Quality Assurance } \\
\text { (ASEAN QA); De- } \\
\text { velopment of ASE- } \\
\text { AN credit transfer } \\
\text { system (ACTS) and } \\
\text { ASEAN-EU credit } \\
\text { transfer systems } \\
\text { (AECTS); ASEAN } \\
\text { and ASEAN-EU } \\
\text { mobility Scholar- } \\
\text { ships. }\end{array}$ & $\begin{array}{l}\text { It contradicts the } \\
\text { goals of regionaliza- } \\
\text { tion and cooperation } \\
\text { with the EU and } \\
\text { regional identity; } \\
\text { compulsion }\end{array}$ & $\begin{array}{l}\text { Will promote, support } \\
\text { and enhance mobility } \\
\text { within ASEAN and } \\
\text { ASEAN-EU }\end{array}$ \\
\hline
\end{tabular}

Using the example of the history of the regional Institute of higher education SEAMEO RIHED [37] we can trace some features of regionalization in South-East Asia:

RIHED was originally established in Singapore in 1959 as a Regional Institute of higher education. RIHED was reorganized and established in Thailand in 1993 as a regional center of SEAMEO. The key role of the initiator and leader belongs to the government of Thailand therefore the head office is located in Bangkok.

SEAMEO is a regional intergovernmental organization of Ministers of education of South-East Asia, established in 1965 to promote cooperation in the field of education, science and culture in the region. The Secretariat and the regional canters SEAMEO have done fruitful work 
on the implementation of programs of education, research and development.

SEAMEO RIHED plays a crucial role in building the capacity of SEAMEO member countries in higher education. More focused on issues related to policy planning, administration and management in higher education.

The mission of SEAMEO RIHED is to improve the management and harmonization of higher education in Southeast Asia through systematic research, empowerment, and the development of mechanisms to facilitate exchange and cooperation in higher education.

The goals of SEAMEO RIHED:

1. To assist Member States in enhancing the effectiveness of the policies, planning, administration and management of higher education systems through training and policy-oriented research, taking into account the special needs, pressing problems and cultural factors of individual Member States for the integrated development of human resources.

2. To serve as a regional center and clearing house for information and documentation of higher education, facilitating the exchange and dissemination of information and research results on the planning and management of higher education both within and outside the region. To promote cooperation among Member States to build institutional ties and assist them in strengthening institution building and development.

The current SEAMEO RIHED Programs include five interconnected areas reflecting its main functional goals, to facilitate access to best practices and synergies in higher education in the region:

- Empowerment of higher education institutions;

- Promotion of social responsibility and sustainable development of the university;

- Cultivating the globalization aspects of human resources;

- Development of harmonization mechanisms;

- Promotion of the boundaries of knowledge in the management of higher education.

Understanding the importance of solving the problems of education in the region affects geopolitical and geoeconomic reasons, where the new actor in Southeast Asia - China plays an important role. The history of the geopolitical relations of China and Thailand is changing and strengthening for the better: Thailand was a conductor in Southeast Asia for China; China's interests are now global; therefore, in the genesis of SEAMEO RIHED, expanding opportunities to the status of an intergovernmental organization aimed at SEA to a greater extent demonstrates the importance of regional issues for other actors in SEA.

The HEAD Foundation experts [38] emphasize the higher level of inter-regional cooperation between regional networks in East Asia at present. The goal should be to mitigate any geopolitical tensions that are characteristic of regionalization in East Asia today, and to develop effective ways to share knowledge and resources in regional networks with to equalize WHO's benefits in the region. Perhaps in this way, East Asian regionalization may begin to move towards a more comprehensive regionalization program to create a single community of Asian countries.

\section{- Mass character of education, diversification and differentiation of the sector}

The mass character of higher education as a consequence of globalization, lack of qualified labor resources, availability of education for a certain segment of the population, led to the emergence of some private universities that provide diplomas, but not quality education; equating engineering universities and colleges to the status of the University, ultimately discredited the concept of research University in the Western sense, the active copying of which falls on the end of the XX century and the first half of the XXI century in the South-Eastern region.

- Academic mobility: outgoing and incoming

https://adamalemijournal.com

ISSN 1999-5849 
Southeast Asian countries are among the twenty-five countries that send their students to study at US universities: Vietnam (8th place), Indonesia (19th), Thailand (20th) and Malaysia (24th); by 2011, 214 thousand citizens of the four listed countries and the Philippines were studying in the USA, Great Britain and Australia; It is associated with the dissemination of various forms of international educational programs implemented in Southeast Asia together with foreign universities (opening branches of Western universities, implementing franchising educational programs, etc.); There are 25 branches of foreign universities in the region (Indonesia (1), Malaysia (6), Singapore (13), Thailand (3), Vietnam (2)).

Outgoing mobility leaders - Singapore and Malaysia (20 countries) - are striving to become regional educational hubs, and have begun to export educational services. According to the Guardian newspaper, in 2014, 52,959 foreign students from 120 countries studied in Singapore, and 63,625 students from 160 countries studied in Malaysia. Most of the foreign students studying in them came from South Korea, China and India, Australia, England, the United Arab Emirates, Oman, Yemen, Saudi Arabia, and Lebanon.

Problems of academic mobility: the peripheral position (the peripheral nature of world science, wealthy locals send their children to British universities); brain drain (young scientists leave for Japan or the West; $100 \%$ of Vietnamese school graduates and winners of international Olympiad's study and work in developed countries; language barrier (development of science in the local language, there are no Englishlanguage programs with the exception of Singaporean, Filipino, Thai) [39].

\section{- Academic culture and corruption}

Despite the collective progress of higher education in East Asia, it is worth noting the destructive academic environment in the region. Academic culture implies values, ideas and beliefs in relation to their profession, which unite teachers and scientists. This affects how and with whom decisions are made, how they act and communicate with each other - at a practical and symbolic level. The following are applicable to the description of the academic culture of East Asia: "honesty", "ethics", "unfair behavior", "corruption". Academic culture based on the values of meritocracy, freedom and competition is a goal and the need for Asian universities.

Unfair behavior is common among teachers and students: in Hong Kong, Taiwan, Japan (Haruko Obokata was improved in fake and plagiarism); in China, the decline began in the early 90s, reflecting the situation in society (administrative positions are more advantageous than academic ones). The concept of "Guansi": the presence of ties connections with senior officials; restriction of freedom of movement of teachers, staff, students, resources; decisions based on personal relationships; falsification of data and plagiarism in the scientific community; purchase of government grants; as a result, the negative impact on the modernization of education in the region; moral and ethical degradation, retarding the scientific development of the region; since 2000, the Chinese government introduced new rules and standards, held forums and seminars, and created anti-corruption agencies and units; Japan is distinguished by its academic culture, has 21 Nobel laureates; until 2014, there was not a single Nobel laureate in SEA.

The problem of corruption in the academic environment of Southeast Asian countries is a consequence of the imbalance of local educational traditions and Western values; the solution is to achieve this balance through synergy and synthesis of institutional and individual activities.

\section{Conclusion}

Experts of the Center for educational development of SKOLKOVO business school prepared a review of the new report of NMC Horizon on the future of higher education for the next five years and identified 10

\section{\begin{tabular}{l|l}
58 & АДАМ ӘЛЕМІ \\
№3 (89) 2021, қыркүйек
\end{tabular}}


global trends in higher education for the next five years (10 future education trends, New Media Consortium Horizon) [40]:

1. The introduction of progressive teaching methods requires cultural transformation.

2. Teaching students real practical skills will help them in further employment, as well as improve their professional skills.

3. Cooperation is a key factor in the dissemination of effective solutions.

4. Although technologies and materials for online learning are widely available, they are still not available to all.

5. It is necessary to create processes to assess skills at the individual level.

6. In order to feel free in the digital world, it is not enough just to be able to use technology.

7. The effectiveness of online learning as well as mobile and blended learning is beyond doubt.

8. Educational ecosystems must be flexible enough to accept completely new teaching methods.

9. Higher education is an excellent environment for developing more intuitive computers.

10. Lifelong learning is the basis of higher education.

For the Asia-Pacific countries, global trends in higher education remain relevant, however, the following trends are more significant: regionalization and its fragmentation; mass character of education, diversification and differentiation of the sector; academic mobility: outgoing and incoming; academic culture and corruption.

\section{References}

1 Vernadsky V. I. Scientific thought as a planetary phenomenon. - M., Science, 1991. $271 \mathrm{p}$.

2 Collins R. Sociology of philosophy: a global theory of intellectual change. - Novosibirsk, Siberian chronograph, 2002. - 1281 p.

3 Torchinov E. A. Ways of philosophy of East and West: knowledge of the beyond. - St. Petersburg: "ABC-classics", "Petersburg Oriental Studies", 2005. - 480 p.
4 Maddison A. Asia in the world economy 1500-2030 AD // Asian Pacific Economic Literature. - 2006. Vol. 20, no.2, pp.1-37.

5 Ross G. Making the International System Work for the Platinum Age. [Electronic resource] (date of the application: 02.09.2020). file:///Users/Sholpan/Downloads/Making_the_ International_System_Work_for_the_Plati.pdf

6 Wan C.D., Morshidi S., Dzulkifli A. R. Education in Malaysia Towards a Developed Nation // Economics Working Paper. - 2017. No.4, 19 p.

7 World Bank Annual Report 2017 [Electronic resource] (date of the application: 05.09.2020).http://headfoundation.org/ research/gsebuffalo/ichefa

8 Johnstone D. Bruce. Financing Higher Education: Worldwide Perspectives and Policy Options // THF Working Papers Series. - 2015. No. 6. - Pp.1-7. [Electronic resource] (date of the application: 05.09.2020).http://headfoundation. org/research/gsebuffalo/ichefa

9 Asian Development Outlook. Supplement: The Outlook Remains Stable. [Electronic resource] (date of the application: 10.09.2020). https://www.adb.org/sites/default/files/ publication/435196/ado-supplement-jul-2018. pdf; Asian Development Bank. Improving Transitions from school to university to workplace. Mandaluyong City, Philippines: Asian Development Bank. [Electronic resource] (date of the application: 10.09.2020).https://www.adb. org/publications/improving-transitions-schooluniversity-workplace; Asian Development Bank: Higher education across Asia: an overview of issues and strategies, 2011, Mandaluyong City, Philippines: Asian Development Bank, 56 p. [Electronic resource] (date of the application: 10.09.2020). https://www.adb.org/sites/default/ files/publication/29407/higher-educationacross-asia.pdf

10 Education Policy Research Series Discussion Document No. 5. Education Systems in ASEAN + 6 Countries: A Comparative Analysis of Selected Educational Issues. Education Policy and Reform Unit UNESCO Bangkok. 2014. [Electronic resource] (date of the application: https://www.right-to-education. org/sites/right-to-education.org/files/ resourceattachments/UNESCO_Education Systems_in_Asia_Comparative_Analysis_2014. pdf: Education in China. A Snapshot. OECD 2016. [Electronic resource] (date of the application: 15.09.2020). https://www.oecd.org/ china/Education-in-China-a-snapshot.pdf

11 British Council. The shape of global higher education: understanding the ASEAN Region. - 2018. - Volume 3. https://www. 
britishcouncil.org/research/shape-globalhigher-education-3; British Council. The shape of global higher education: International mobility of student's research and education provision. - 2017. - Volume 2. [Electronic resource] (date of the application: 17.09.2020). https://www.britishcouncil.org/education/ihe/ knowledge-centre/global-landscape/shapeglobal-higher-education-vol-2

12 HEAD Foundation (Human Capital \& Education for Asian Development). Workshop Reports No. 1. Asian Education Futures. The HEAD Foundation 2015; The HEAD Foundation 2016; THF Workshop Report No 2. Asian Universities in New Times. The HEAD Foundation 2015; THF Workshop Report No 4. Teacher Development: Dimensions \& Perspectives'. The HEAD Foundation 2016. [Electronic resource] (date of the application: 20.09.2020). http:// headfoundation.org/research/gsebuffalo/ichefa

13 National coordination center for the development of economic relations with the countries of the Asia-Pacific region. [Electronic resource] (date of the application: 25.09.2020). http://www.aprcenter.ru/about.htm

14 National research University "Higher school of Economics". [Electronic resource] (date of the application: 25.09.2020). http:// www.hse.ru/

15 SEAMEO RIHED [Southeast Asian Ministers of Education Organization; Regional Center for Higher Education and Development] [Electronic resource] (date of the application: 27.09.2020). https://rihed.seameo.org/about-us/

16 Center for the study of international higher education at Boston College (USA). The Center for International Higher Education' (ClHE). Altbach, Philip J., Reisberg, Liz, Hans de Wit. 2017. Responding to Massification. Differentiation in Postsecondary Education Worldwide. Boston College Center for International Higher Education, 170 p. [Electronic resource] (date of the application: 29.09.2020). http://www.bc.edu/research/cihe/; National research University "Higher school of Economics" (HSE) http://www.hse.ru/

17 Center for Educational Development of SKOLKOVO Business School [Electronic resource] (date of the application: 02.10.2020). http://trends.skolkovo.ru/2017/10/10-trendovbudushhego-obrazovaniya/

18 The Boston Consulting Group is an international company specializing in management consulting, a leading consultant on business strategy. [Electronic resource] (date of the application: 02.10.2020). www.bcg.ru

19 International comparative project on financing and accessibility of higher education
(ICHEFA) of The Graduate School of Education at the state University of New York in Buffalo ('Comparative Higher Education Finance and Accessibility Project (ICHEFA) of the Graduate School of Education at the State University of New York at Buffalo'). [Electronic resource] (date of the application: 05.10.2020). http:// headfoundation.org/research/gsebuffalo/ ichefa

20 Rizvi F. Globalization and the Neoliberal Imaginary of Educational Reform // Education Research and Foresight Series. - Paris, UNESCO. - 2017. - No. 20. [Electronic resource] (date of the application: 10.10.2020).https://en.unesco. org/node/262287;

21 Barber M., Donnelly K., Rizvi S. An avalanche is coming. Higher education and the coming revolution. The issue of education. 2013. - No. 3. - 152-236 pp. [Electronic resource] (date of the application: 10.10.2020). https:// vo.hse.ru/data/2014/08/04/1314334660/20133_Barber\%20et\%20al.pdf

22 Barber M., Donnelly K., Rizvi S. An avalanche is coming. Higher education and the coming revolution. The issue of education. 2013. - No. 3. - 109-185 pp. [Electronic resource] (date of the application: 15.10.2020). https:// cyberleninka.ru/article/n/okeany-innovatsiyatlanticheskiy-okean-tihiy-okean-mirovoeliderstvo-i-buduschee-obrazovaniya

23 Choi W. Edward. Higher Education Regionalization in East Asia (Higher Education in Southeast Asia and Beyond). $\mathrm{MCl}(\mathrm{P})$, June 2017. - No 123. - 7-10 pp. [INTERNATIONAL HIGHER EDUCATION], No. 90, 26-28 pp. [Electronic resource] (date of the application: 20.10.2020).file://Users/Sholpan/Downloads/ Higher_Education_Regionalization_in_East_ Asia.pdf

24 Sycheva V. S. Method of secondary analysis [Sociological research]. - 1995. No.11. [Electronic resource] (date of the application: 23.10.2020). ecsocman.hse.ru/ data/961/889/1216/023Cycheva.pdf

25 New Media Consortium (NMC Horizon) [Electronic resource] (date of the application: 25.10.2020)https://www.nmc.org/nmc-horizon/

26 Johnstone D. Bruce. Financing Higher Education: Worldwide Perspectives and Policy Options // THF Working Papers Series. - 2015. No. 6. Pp. 1-7. [Electronic resource] (date of the application: 05.09.2020). http://headfoundation. org/research/gsebuffalo/ichefa

27 Asian Development Outlook. Supplement: The Outlook Remains Stable. [Electronic resource] (date of the application: 10.09.2020). https://www. adb.org/sites/default/files/publication/435196/ ado-supplement-jul-2018.pdf 
28 Li Jin. Cultural foundations of learning: East and West New York. - New York: Cambridge University Press, 2012. - 385 pp.

29 Japanese and Singapore Education Models, Education Transfer and Comparative Policy Learning Roundtable. [Electronic resource] (date of the application: 25.10.2020). https://headfoundation.org/2016/08/26/ massification-globalisation-and-the-globalknowledge-economy/

30 George Cheryan. Singapore's powerhouses neglect local intellectual life. [Electronic resource] (date of the application:27.10.2020). https://www. timeshighereducation.com/features/singaporespowerhouses-neglect-local-intellectual-life

31 Altbach Philip J. Higher education, mass education and research universities // International higher education. - 2017. Issue 91. - Pp. 10-11.

32 Bothwell, E., Jack G. 2018. 'World University Rankings 2018: results announced', https://www.timeshighereducation.com/worlduniversity-rankings/2018/world-ranking\#!/ page/0/length/25/sort_by/rank/sort_order/ asc/cols/stats

33 Sharma Yojana. New Asian universities' alliance to increase mobility. [Electronic resource] (date of the application: 29.10.2020). http://www.universityworldnews.com/article. php?story $=20170504205518718$

34 Yang Rui. Cultural mission of advanced universities of East Asia // International higher education. - 2017. Issue 91. - Pp. 37-39.

35 Yang Rui. Getting the Mix Right: The Cultural Mission of East Asia's Elite Universities
// Higher Education in Southeast Asia and Beyond. $\mathrm{MCl}(\mathrm{P}), 2017$. - No.123, pp.3-5.

36 HEAD Foundation (Human Capital \& Education for Asian Development). Workshop Reports No. 1. Asian Education Futures. The HEAD Foundation 2015; The HEAD Foundation 2016; THF Workshop Report No 2. Asian Universities in New Times. The HEAD Foundation 2015; THF Workshop Report No 4. Teacher Development: Dimensions \& Perspectives. The HEAD Foundation 2016. [Electronic resource] (date of the application: 20.09.2020). http:// headfoundation.org/research/gsebuffalo/ ichefa

37 SEAMEO RIHED [Southeast Asian Ministers of Education Organization; Regional Center for Higher Education and Development] [Electronic resource] (date of the application: 27.09.2020). https://rihed.seameo.org/about-us/

38 Choi W. Edward. 2017. Higher Education Regionalization in East Asia (Higher Education in Southeast Asia and Beyond), June 2017. MCl (P), No 123, 7-10 pp. [INTERNATIONAL HIGHER EDUCATION], No. 90, 26-28 pp. [Electronic resource] (date of the application: 20.10.2020). file:///Users/Sholpan/Downloads/Higher. Education_Regionalization_in_East_Asia.pdf

39 Thu T. Do, Dui N. Problems of student mobility in Southeast Asia // International higher education. - 2016. Issue 84. - 29-30 pp.

40 New Media Consortium (NMC Horizon) [Electronic resource] (date of the application: 29.10.2020) http://trends. skolkovo.ru/2017/10/10-trendov-budushhegoobrazovaniya/

\section{INFORMATION ABOUT AUTHORS}

Sholpan Ibzharova

Gulnar Koyanbayeva

Шолпан Айдаралықызы Ібжарова

Гүлнар Ромсеитовна Қоянбаева

Шолпан Айдаралиевна Ибжарова

Гульнар Ромсеитовна Коянбаева
Candidate of Philosophical Sciences, Professor, Almaty Management University (AlmaU), Almaty, Kazakhstan

Candidate of Philosophical Sciences, Leading Researcher, Institute for Philosophy, Political Science and Religious Studies of the CS MES RK, Almaty, Kazakhstan

философия ғылымдарының кандидаты, профессор, Алматы менеджмент университеті, Қазақстан, Алматы

философия ғылымдарының кандидаты, жетекші ғылыми қызметкер, ҚР БҒМ ҒК Философия, саясаттану және дінтану институты, Алматы, Казахстан

кандидат философских наук, профессор, Алматы менеджмент университет, Алматы, Казахстан

кандидат философских наук, ведущий научный сотрудник, Институт философии, политологии и религиоведения КН МОН РК, Алматы, Казахстан 